\title{
The Ancient Greek Discovery of the Nervous System: Alcmaeon, Praxagoras and Herophilus
}

\begin{abstract}
This paper shows that Alcmaeon and his theories were an important part of a developing conception of the brain and the nervous system. The vital contributions of Praxagoras of Kos, who suggested the existence of what we now call "neurons", and Herophilus of Chalcedon, who distinguished between sensory and motor nerves and proved the existence of the nervous system by dissection, also established the foundation principles of neuroscience - though their role is sometimes forgotten. In this essay we trace the discovery of the nervous system through the investigations of these three thinkers. Combining astounding philosophical concepts with sharp observation, they conceived and demonstrated the existence of a nervous system by the 3rd Century BC. This discovery is central not only to neuroscience, but also to all of medicine and to our concept of the human organism; for it revealed the connection between the intelligent mind, the brain, and the body.
\end{abstract}

Keywords: Nervous system; Ancient greek; Alcmaeon; Praxagoras; Herophilus

Received: July 09, 2015; Accepted: August 07, 2015; Published: August 10, 2015

\section{Konstantine PP ${ }^{1}$ and Peter KP ${ }^{2}$}

1 School of Historical and Philosophical Studies, The University of Melbourne, Parkville, Victoria, Australia

2 Neurodegenerative Disorders Research Pty Ltd, 4 Lawrence Avenue, West Perth 6005, Western Australia

\section{Corresponding author: Panegyres PK \\ $\equiv$ research@ndr.org.au}

Neurodegenerative Disorders Research Pty Ltd, 4 Lawrence Avenue, West Perth, Western Australia 6005.

Tel: +61 894816293

Fax: +61 894816294

Citation: Konstantine PP, Peter KP. The Ancient Greek Discovery of the Nervous System: Alcmaeon, Praxagoras and Herophilus. J Neurol Neurosci. 2015, S1.

\section{Introduction}

Medicine began with inquiry into the structure, composition, and form of the body [1]. Like the Egyptians and Babylonians, whose medical tradition was based on a combination of traditional magical and religious methods ${ }^{a}$, some philosophers in Greece sought to develop a detailed anatomical understanding of the body [2]. In the 6th Century, philosophers began to consider that it might be possible to detect animal illness and disease by investigation into the structure of the human organism [2]. The rationale for some doctors therefore became the extensive documentation and theorisation about the different parts of the body: their function, purpose, and inner workings. The problem in medicine, through all this period, was learning of the cause

\footnotetext{
a The most important points to acknowledge are (i) Greek medicine was 'rational' but not in the modern sense of the term: the 'rational' included magic, Gods, and spirits (ii) the Gods were part of nature to the Greeks, and therefore the investigation of the soul and evil spirits was considered an inquiry into nature (iii) there is no evidence to suggest that the new 'rational' approach to medicine as the works of Alcmaeon et. al. are often described (e.g. in Longrigg) was any more successful than old medical practice: to the average person on the street, the elitist academic work of now well known-physicians such as Hippocrates and Galen was both unsuccessful in curing daily illness or assisting health and seen as remote in the same way as the philosophical writings of Plato might have been remote to the person not academically trained to a high standard of philosophical dialectic.
}

of illness. Physician-philosophers such as Alcmaeon, and, in later centuries physicians, Praxagoras and Herophilus, attempted to understand the biological form and function of the brain, and its relationship to the rest of the body [3]. Within this atmosphere of philosophical inquiry, questions about the nature of the mind arose [4]. From this inquiry came the origins of neuroscience and neurology.

\section{Alcmaeon of croton and his theory of the brain}

Alcmaeon of Croton (Figure 1A) lived in the city of Crotone in Magna Graecia (now southern Italy) around the beginning of the 5th Century BC [5]. He was a philosopher-physician. His works cover topics ranging from the details of the optic nerve to observations regarding the nature of the soul ${ }^{b}$ [3]. Some scholars argue that he was a member of the Pythagorean school of philosophy and had been a pupil of Pythagoras, but there is no agreement over this and the evidence is inconclusive [1]. It can nonetheless be said that Alcmaeon's work was philosophical in

${ }^{\mathrm{b}}$ Alcmaeon believed in the immortality of the soul. It is perhaps this reason that led Plato to adopt Alcmaeon's encephalocentric model of the human being. It is in the Phaedo that Socrates refers to the brain as the central organ of sense. Many scholars believe Plato is directly referring to Alcmaeon. 
nature ; it aimed, not merely to observe, but also to understand the nature of things [6].

The main theories of Alcmaeon relating to the brain are provided in summary below.

\section{Human beings can both perceive and understand}

Unlike animals, who can merely perceive, human beings have the capacity to interpret and place meaning on the objects they perceive [7]. For Alcmaeon, thinking and perceiving are two different things. Human beings are capable of understanding because they can perceive and think about what they perceive.

\section{The brain is the centre of the senses}

All the perceptions of which human beings are capable are connected to and transmitted from the brain. These sensations pass through passages which run to and from the brain. When the brain suffers some disaster, these passages are severely impeded, leading to the inability to move or feel [7]. Because all the senses transfer what they perceive to the brain so that it can be decoded, the brain is essential for perception [8].

\section{Intelligence resides in the brain}

The brain is hegemonic in the body [7]. The brain dictates not merely physical and mental function but also coordinates the relationship between the two. Mind and body are therefore not necessarily distinct, separate entities.

\section{Smell is understood through the brain}

When air is sucked up through the nostrils the smell is transmitted to the brain [9].

\section{Mental maturity is attained around the age of fourteen}

It is at this age that human beings become capable of reasoning and intuitive analysis of data presented to the brain [10].

Good health depends on the equilibrium of bodily faculties

In order to remain healthy, a human being must maintain a state of equilibrium in the body. The body, Alcmaeon states, contains opposites which work against each other: hot and cold, moist and dry, fast and slow, bitter and sweet, and others [7]. Each part of the body relies on another, but all these functions exist under the hegemony of the brain. Disease occurs where excess of one opposite exists (e.g. cold) or where there is a dire lack of one opposite (e.g. sustenance). Alternately, disease can occur when there is a fault in one part of the body (e.g. the brain) that affects all other parts adversely [7]. This idea presages Claude Bernard's concept of the constancy of the internal environment, a fundamental physiological principle: if say, there is low sodium, the body will correct it, otherwise disease will reign.

\section{Eyes transmit perception}

The eyes are connected to the brain by an optic nerve [10]. The

${ }^{c}$ At this period in time, philosophy was not seen as a distinct and separate discipline; rather, it formed the basis of inquiry for the majority of disciplines. eyes contain both water and fire; water, because the eyes are soft and wet and gluggy; fire, because the eyes when struck produce flashes in the mind [7]. The diaphanous water in the eye allows it to reflect an image better because water is clear and pure [11]. The observation that the eyes are connected to the brain is said to have been the result of dissections which revealed that the optic nerve leads to the brain [12].

\section{Ears transmit sound}

The ears resonate and carry sound. The ears, Alcmaeon argues, are empty. Since all cavities resonate sound, and since the ears are empty and therefore cavities, the ears resonate sound when sound enters into them. Alcmaeon suggests that sound is conveyed first to an outer chamber, and then, by reverberating there, the sound is carried to the brain [12].

\section{Passages connect sensory organs to the brain}

There are passages which connect sense organs to the brain [13]. Alcmaeon calls these passages rópoı (poroi) [11]; this word, like most Ancient Greek words, has many different meanings: 'pores', 'channels', 'paths', 'openings'; but in biology it can also mean 'fibers' or 'threads'. Taking into consideration this biologically directed meaning and Alcmaeon's observations that the senses are connected to the brain [7], it is possible that Alcmaeon posited the existence of channels which connected the brain with all other parts of the body. This is supported by Alcmaeon's observations of rópo in the eyes and ears [11], most likely the optic nerve and the cochlear and vestibulocochlear nerves.

Alcmaeon's theories, based on his empirical investigations, suggest, first, the idea that "brain creates mind" [8], and, second, the idea that the brain is connected to the rest of the body by channels ( $\pi$ ópoı). Alcmaeon thus conceives of the brain as the nucleus of all human perception. These were significant developments in the understanding of cognition and perception. Alcmaeon's investigations and theories were, however, provisional; so far as scholars are aware, his ideas were not conclusively proved or extended upon in his lifetime, and the doxographical writings in which his works were recorded were often prone to ornamentation [14]. Although Alcmaeon might have correctly established the link between the brain and mind, he did not himself articulate any specific scientific view regarding the nature of the nervous system that can be safely said to be a view about the nervous system as it was later conceived [1]. It has, for instance, been argued that he believed the rópo to be an extended part of the brain, just as he thought sperm to be a part of the brain [9], rather than an instrument connected to the brain's faculty of perception ${ }^{\mathrm{d}}$. Nonetheless, his work, even in its most basic form, laid the theoretical groundwork for further investigations into the nature of the brain.

\section{Praxagoras and Herophilus}

The questions raised by Alcmaeon influenced all medical researchers for the following thousand years. Understanding

\footnotetext{
d There are further problems with Alcmaeon's theory. It is possible that Alcmaeon conceived of these channels as pores through which the soul or pneuma flowed. This agrees with Alcmaeon's concept of the arteries as empty tubes containing not blood but pneuma; it also corresponds more closely to what the fragments record of his writings. These points do not, however, detract from the more important advancements he made.
} 
the causes of bodily movement and the role of mental agency became an important philosophical question. A rational approach towards medicine and a sceptical attitude towards tradition were increasingly seen as the only means to solve this problem put forward by natural philosophy [4].

Praxagoras, a natural philosopher who lived in the 4th Century $B C$ [15], held this view. Praxagoras' main contribution as a philosopher seems to have been the first to make a general, explicit distinction between arteries and veins and to explain their different functions [15]. His main contribution as a teacher of neurology, however, was to ask his students, one of whom was Herophilus of Alexandria, how it is that the intention of movement is transmitted to the bodily extremities [1]. Though Alcmaeon had provided the beginnings of an answer to the question in the previous century, the theories had neither been properly tested nor thoroughly proved by examination of the body.

Praxagoras answered his own question by postulating that there were in the body miniscule arteries that were responsible for transmitting signals through the body. Some arteries became so thin at their endings that their lumen (koilotès) virtually disappeared. For this final part he used the word "neuron" (vยũ $\alpha$ av), which was the Greek word for 'cord' or 'sinew'. The nerves were no longer "poroi". Praxagoras did not himself locate and identify neurons, however.

After Alcmaeon's original hypotheses, this was the second important development in the history of neurology.

Herophilus of Kos (Figure 1B) was a student of Praxagoras, and so learnt about and discussed the theories of Alcmaeon and Praxagoras. He was born in Chalcedon, Asia Minor (now Turkey) in the late 4th Century BC, but did his important work in Alexandria.

Herophilus was the first to examine and report on the structure of the nervous system. He was able to do this by dissecting human cadavers [15], a practice that was in many places abandoned until the 16th Century [16]. This method allowed him to make many discoveries.

Herophilus showed that the nervous system was distinct and separate from the cardiovascular system [15]. He noted the different function of sensory and motor nerves [1], something

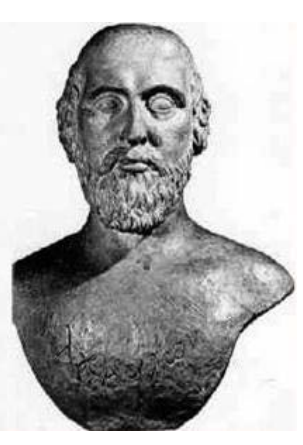

(A) Alcmaeon of Croton

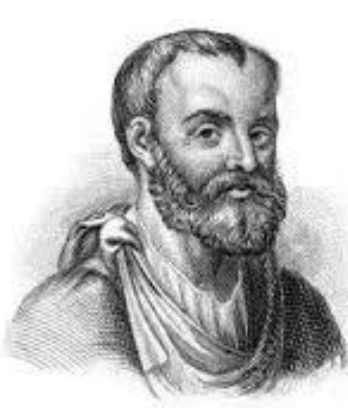

(B) Herophilus of Kos
Figure 1 Artisticimpressions. neither Alcmaeon nor Praxagoras hypothesised. In examining these nerves by dissection of the spinal regions, he was able to observe that they originate in the brain and are threaded throughout the whole body [1]. These discoveries were accompanied by the realisation that motor nerves were joined to muscles and sensory nerves to organs of sensation [15]. In so doing, Herophilus proved-and indeed improved upon-the earlier theories of Alcmaeon and Praxagoras.

In addition, Herophilus distinguished between the cerebrum and cerebellum and measured the pulse of blood through the body. In making his observations, Herophilus was one of the first in history to acknowledge and correctly articulate the separate systems contained within the body and to prove the particular primacy of the brain as the prime mover of those systems. Herophilus' discoveries, and the theories of Alcmaeon and Praxagoras upon which they were built, can therefore be considered as the foundations of neuroscience and neurology $\mathrm{e}^{\mathrm{e}}$.

\section{Conclusion}

Considering the technological limitations of their age, the ideas and discoveries of Alcmaeon, Praxagoras, and Herophilus can be greatly appreciated for the power of their thought, the keenness of their observation, and the logic of their theories (Table 1). The encephalocentric model to which Alcmaeon and Herophilus adhered, and which was praised by Plato but rejected by Aristotle, proved not only that the brain was the seat of the mind, but also that it was connected to a complex nervous system which was threaded throughout the body. The idea of a nervous system is now central not only to neuroscience, but also to all anatomy; it is the link between the mind and the body.

'It is also worth acknowledging the work of Herophilus' contemporary, Erasistratus However, like Alcmaeon, Erasistratus believed that the nervous system was filled with pneuma or soul-spirit which fills the body with life. There is no evidence that Herophilus agreed with this point, and all the extant documents suggest that Herophilus believed the threads that constitute the nervous system merely to carry signals and link the brain to the body.

Table 1: The discovery of the nervous system: A summary.

\begin{tabular}{|c|c|c|}
\hline Philosopher & Date & Theory/Discovery \\
\hline \multirow[b]{2}{*}{$\begin{array}{c}\text { Alcmaeon of } \\
\text { Croton }\end{array}$} & \multirow[b]{2}{*}{$\begin{array}{l}\text { Late } 5 \text { th - } \\
\text { Early 4th } \\
\text { Century BC }\end{array}$} & 1. The brain is the seat of intelligence. \\
\hline & & $\begin{array}{l}\text { 2. The brain is connected to the } \\
\text { extremities of the body by 'passages' } \\
\text { (poroi) which run through the body. }\end{array}$ \\
\hline \multirow{2}{*}{$\begin{array}{l}\text { Praxagoras } \\
\text { of Kos }\end{array}$} & \multirow{2}{*}{$\begin{array}{l}\text { Born c. } 350 \\
\text { BC Died (?) }\end{array}$} & $\begin{array}{l}\text { 1. Asks his students what it is that } \\
\text { allows the brain to control movement in } \\
\text { the body. }\end{array}$ \\
\hline & & $\begin{array}{l}\text { 2. Posits the existence of neurons that } \\
\text { are responsible for sending brain signals } \\
\text { through the body. }\end{array}$ \\
\hline \multirow{3}{*}{$\begin{array}{l}\text { Herophilus of } \\
\text { Chalcedon }\end{array}$} & \multirow{3}{*}{$\begin{array}{c}\text { c. } 335-280 \\
\text { BC }\end{array}$} & $\begin{array}{l}\text { 1.By dissection, proved the existence of } \\
\text { a nervous system, as distinct from the } \\
\text { vascular system. }\end{array}$ \\
\hline & & $\begin{array}{l}\text { 2.Distinguished the cerebrum and the } \\
\text { cerebellum and their different functions. }\end{array}$ \\
\hline & & $\begin{array}{l}\text { 3.Discovered nerves connecting to inner } \\
\text { organs or muscles and was the first to } \\
\text { distinguish between sensory and motor } \\
\text { nerves. }\end{array}$ \\
\hline
\end{tabular}


In attempting to demonstrate their theories through dissection and extended observation, these physician-philosophers provided a sound exemplum for future medical research and discovery. The work of the one would have been insignificant without the perseverance of the other: Alcmaeon, Praxagoras, and Herophilus all relied on and believed in the possibilities that can arise from testing theories through observation and relentless query. And despite the intriguing theories propounded by Alcmaeon, it took his successors to correct, refine, and advance his ideas in astonishing new directions. Testament to their lives is the fact that their basic ideas and observations remain the foundation of neurological research done today.

\section{Declarations}

Competing interests: None declared

Funding: Neurodegenerative Disorders Research Pty Ltd

Ethical approval: Not applicable

\section{Guarantor: PKP}

Contributorship: Both authors contributed equally but brought different expertise to the article. KPP provided the translations of the Greek and Latin texts and assessed the classical sources and secondary literature. PKP provided the neurological insights and clinical experience, and added to the technical aspects of the material.

\section{Acknowledgements: None}




\section{References}

1 Longrigg J (1993) Greek Rational Medicine. Oxford: Routledge.

2 Ferngren GB (2014) Medicine and Religion: An Historical Introduction. Baltimore: Johns Hopkins University Press.

3 Gross CG (1997) From Imhotep to Hubel and Wiesel: The Story of the Visual Cortex. Cerebral Cortex 12: 843-846.

4 Frede M (1987) Essays in Ancient Philosophy. Minneapolis: University of Minnesota Press.

5 Mavrodi A, Paraskevas G (2014) Morphology of the heart associated with its function as conceived by ancient Greeks'. International Journal of Cardiology 172: 23-28.

6 Lloyd G (1975) Alcmaeon and the early history of dissection. Sudhoffs Archiv 59: 113-147.

7 Diels H (1879) Doxographi graeci. Berlin: Reimer.

8 Doty RW (2007) Alkmaion's discovery that brain creates mind: a revolution in human knowledge comparable to that of Copernicus and of Darwin. Neuroscience 147: 561-568.

9 Codellas PS (1931-1932) Alcmaeon of Croton: His life, work and fragments. Proceedings of the Royal Society of Medicine 25: 1042.

10 Hermann KF (1892) Dialogi Platonis. Manhattan: Harper Brothers Press.

11 Wachtler I (1896) De Alcmaeone Crotoniata. Oxford: Teubner.

12 Beare Jl (1906) Greek Theories of Elementary Cognition from Alcmaeon to Aristotle. Gloucestershire: Clarendon Press 93-94.

13 Menake GT (2004) Three Traditions of Greek Political Thought: Plato in Dialogue, Maryland: University Press of America.

14 Long A (1999) The Cambridge Companion to Early Greek Philosophy. Cambridge: Cambridge University Press 22-23.

15 Staden HH (1989) The art of medicine in early Alexandria: Edition, Translation and Essays. Cambridge: Cambridge University Press 44.

16 Pearce JMS (2013) The Neurology of Erasistratus. Journal of Neurological Disorders 1: 1.

An Original publication of ImedPub in a Special Issue-Current Trends in Neurodegenerative Diseases and Medical Procedures, Edited by Dr. Jianqi Cui, Department of Biochemistry and Molecular Biology, School of Basic Medical Sciences, Ningxia Medical University (NXMU), PR China. 